\title{
Effect of Consortium of Endophytic Nitrogen Fixing Bacteria on Nutrient Uptake and Soil Nitrogen Balance Study of Seasonal (SURU) Sugarcane under Drip Irrigation
}

\author{
B. Rajkumar* and B.D. Bhakare \\ Department of Soil Science and Agricultural Chemistry, Post Graduate Institute, Rahuri \\ (MPKV), Ahmednagar, Maharashtra-413722, India \\ *Corresponding author
}

\begin{tabular}{|c|c|}
\hline & \\
\hline Keywords & \multirow{3}{*}{$\begin{array}{l}\text { The present investigation entitled "Effect of consortium of endophytic nitrogen fixing } \\
\text { bacteria on yield and quality of seasonal (Suru) sugarcane (Saccharum officinarum) under } \\
\text { drip irrigation" was carried out at AICRP on Water Management, M.P.K.V., Rahuri during } \\
2014-15 \text {. The experiment was laid out in Randomized Block Design with six treatments } \\
\text { and four replications. There were four levels of nitrogen }(100 \%, 50 \%, 25 \% \text { and } 0 \% \text { ) with } \\
\mathrm{P}_{2} \mathrm{O}_{5}, \mathrm{~K}_{2} \mathrm{O} \text {, PSB, FYM and foliar application of consortium of endophytic nitrogen fixing } \\
\text { bacteria with and without combination and set treatment of Acetobacter diazotrophicus. } \\
\text { The results of the experiment conducted revealed that the higher total nutrient uptake for } \\
\mathrm{N}, \mathrm{P} \text { and K }\left(243.91,60.20 \text { and } 205.47 \mathrm{~kg} \mathrm{ha}^{-1} \text {, respectively) was recorded in the treatment }\right. \\
25 \% \mathrm{~N}+\mathrm{Consortium} \text { of Endophytic Bacteria foliar spray. Soil nitrogen balance study } \\
\text { revealed that there was a negative balance of nitrogen in all the treatments except RDF } \\
100 \% \mathrm{~N} \text { which has positive balance. }\end{array}$} \\
\hline Article & \\
\hline & \\
\hline
\end{tabular}

\section{Introduction}

Sugarcane (Saccharum spp. hybrid) is a tall, perennial grass (family Poaceae, subfamily Panicoide), and is cultivated in tropical and warm-temperate regions between $35^{\circ} \mathrm{N}$ and $35^{\circ} \mathrm{S}$ and from sea level to altitudes of 1,000 $\mathrm{m}$ in a wide variety of soil types (Reis et al., 2007). Most of the commercial sugarcane varieties are hybrids with Saccharum officinarum. The optimal temperature for sugarcane cultivation is between 20 and $35^{\circ} \mathrm{C}$ and the minimum rainfall requirement is $1,200 \mathrm{~mm}$ per year (Ando. 2010). The stalks (stems) of sugarcane are harvested at 9 to 18 months after planting the mother stem cutting (setts). Once planted, sugarcane can be harvested several times, because new stalks, called ratoons, repeatedly grow from the stubble. For many years, sugarcane has been used for sugar and an alcoholic drink production. It grows up to 2-6 $\mathrm{m}$ in height. In 2011, world production of sugarcane was 1,794 million tons (FAO STAT, 2011) which is much higher than other major crops such as maize (883 million tons), paddy rice (723 million tons), wheat (704 million tons) and potatoes (374 million tons). Sugarcane production is highest in Brazil (734 million tons), followed by India (342 million tons), 
and China (115 million tons). Sugarcane was cropped over an area of 25 million hectares all over the world; the average yield was 70.5 tons per hectare. It has occupied 40.75 lakh ha. area in India, while 7.36 lakh ha. in Maharashtra state. Sugarcane being a long duration crop produces huge amount of biomass, and requires large quantity of water (1100-2200 mm) and is mostly grown as an irrigated crop using surface irrigation. The drip irrigation adoption in sugarcane increases water use efficiency (60-200\%), saves water (20-60\%), reduces fertilization requirement (20-33\%) through fertigation, produces better quality crop and increases yield (7-25\%) as compared with conventional irrigation. However, if not installed properly, it may result in wastage of water, time, money and yield. Nitrogen is essential and primary nutrient, required by all crops in large amount. However, nitrogenous fertilizers added in soil get leached out or washed out. It not only causes economic loss but also leads to soil pollution, water pollution and environmental pollution. It causes harm to soil health as well as human health. The use of biofertilizers to some extent are useful and ecofriendly option to overcome these problems. Endophytic nitrogen fixing bacteria are associative type nitrogen fixers. They fix nitrogen by staying in tissues. Mostly they are present in sugar containing plants. Biological nitrogen fixation is the potential biological process that maintains the soil nitrogen status under normal conditions. In recent years nitrogen fixation by G.diazotrophicus in sugar rich crops has been well established. Biological nitrogen fixation effectively supplemented the need of nitrogen and minimizes the cost of production by reducing doses of nitrogenous fertilizers. Endophytic nitrogen fixation concept has been recently gaining momentum. Cultivation in the tropical regions entails least input package of practices and soils are generally low in the nutrient status (Dakora and Phillips, 2002) thus biologically fixed nitrogen can supplement the nitrogen requirement of the crops. Major studies of endophyic diazotrophs are focused on sugarcane and kallar grass (Dobbelaeve et al., 2003) thus indentification of diazotrophs from other economically important plants is of considerable value for sustainable agriculture. It has been suggested to be an endophytic contributor of nitrogen to sugar rich crops, as it fixes nitrogen in culture medium under acidity levels, sugar concentration and micro aerobic conditions that resemble those inside the plants and it fixes or accumulates nitrogen to sugar rich plants between 10 to180 $\mathrm{kg}$ per hectare per season.

\section{Materials and Methods}

The investigation was carried out at AICRP on Water Management, M.P.K.V., Rahuri during 2014-15. Soil was medium black it belongs to Inceptisols. The climate of this area is semiarid. The seedling material of sugarcane Co.M -0265 (Phule - 0265) was procured from Chief Scientist, AICRP on Water Management, Department of Agronomy, M.P.K.V., Rahuri. The experiment was laid out in RBD design with four replications and six treatments including one control and one recommended dose of fertilizers. Basal dose of nitrogen, phosphorus, and potassium i.e. recommended dose $\left(250: 115: 115 \mathrm{~kg}\right.$ of $\mathrm{N}, \mathrm{P}_{2} \mathrm{O}_{5}$ and $\mathrm{K}_{2} \mathrm{O}$ ha ${ }^{1}$ ) along with organic manures i.e. full dose of FYM, Acetobacter diazotrophicus and PSB as per the different treatment details per plot and replication wise were given before transplanting of seedlings. Remaining doses of fertilizers were applied at 6-8, 12-14, 18-20 weeks after transplanting i.e. top dressing. Consortium of Endophytic Bacteria foliar spray were taken at 60 days after transplanting for treatments 4 and 5 in all the four replications. Two hand weedings were carried out to keep plots free from weeds. Irrigation schedule for drip at alternate day as per $100 \%$ ETc was fixed. 


\section{Details of treatments}

$\mathrm{T}_{1}$ - Absolute control (No fertilizers),

$\mathrm{T}_{2}-\mathrm{RDF}\left(100 \% \mathrm{~N}, \mathrm{P}_{2} \mathrm{O}_{5}\right.$ and $\left.\mathrm{K}_{2} \mathrm{O}\right)$

$\mathrm{T}_{3}-50 \% \mathrm{~N}+$ Acetobacter diazotrophicus @ $10 \mathrm{~kg} . h a^{-1}$ (set treatment)

$\mathrm{T}_{4}-25 \% \mathrm{~N}+$ Consortium of Endophytic Bacteria@ $3 \mathrm{~L} \mathrm{ha}^{-1}$ (500L water ha ${ }^{-1}$ ) [foliar spray at $60 \mathrm{DAT}]$

$\mathrm{T}_{5}-0 \% \mathrm{~N}+$ Consortium of Endophytic Bacteria@3 L ha ${ }^{-1}\left(500 \mathrm{~L} \mathrm{ha}^{-1}\right)$ [foliar spray at $60 \mathrm{DAT}]$

$\mathrm{T}_{6}-0 \% \mathrm{~N}+$ without Consortium of Endophytic Bacteria.

NOTE: - $75 \% \mathrm{P}_{2} \mathrm{O}_{5}, 100 \% \quad \mathrm{~K}_{2} \mathrm{O}, 20$ t.ha $^{-1}$ FYM, $1.25 \mathrm{~kg} \cdot \mathrm{ha}^{-1}$,

PSB common to all treatments except $T_{1}$.

The Consortia of Endophytic Nitrogen fixing bacteria was applied as foliar application@3 lit $\mathrm{ha}^{-1}$. (500 lit water) at 60 days after transplanting.

The following endophytic bacteria are the components of consortia:

\section{Acetobacter}

Agrobacterium

Burkhloderia

Azospirrillum

Herbaspillum

Azoarcus

\section{Nutrient uptake (leaf and cane)}

The cane and fourth leaf samples were collected at harvest and were dried in the oven at $60^{\circ} \mathrm{C}$ till constant weight is achieved. The samples were ground to fine powder with the help of whilly mill and then were further digested in Kjeldahl digestion unit (48 tubes set) at required temperature as suggested by (Parkinson and Allen 1975). Then acid extract was used for determining the concentration of $\mathrm{N}, \mathrm{P}, \mathrm{K}$ by using standard methods of analysis

The data was analyzed statistically by using randomized block design as per procedure described by (Panse and Sukhatme 1985).

\section{Results and Discussion}

\section{Nutrient uptake}

The data on the total nutrient uptake of seasonal sugarcane are presented in Table 01 .

The treatment $\mathrm{T}_{4}-25 \% \mathrm{~N}+$ consortium of endophytic bacteria foliar spray recorded the highest uptake of nutrients by cane for N, P and $\mathrm{K}$ (236.03, 58.46 and $198.70 \mathrm{~kg} \mathrm{ha}^{-1}$, respectively).

The lowest uptake of N, P and K (112.49, 29.98 , and $79.22 \mathrm{~kg} \mathrm{ha}^{-1}$, respectively) was recorded in the treatment $\mathrm{T}_{1}$ (absolute control).

The treatment $\mathrm{T}_{2}-\mathrm{RDF}$ recorded the highest $\left(8.12 \mathrm{~kg} \mathrm{ha}^{-1}\right)$ uptake of nitrogen by sugarcane top which was at par with $\mathrm{T}_{4}\left(7.88 \mathrm{~kg} \mathrm{ha}^{-1}\right)$ and the highest uptake of phosphorus and potassium (1.90 and $7.45 \mathrm{~kg} \mathrm{ha}^{-1}$, respectively) by top was recorded in treatment $\mathrm{T}_{5}-0 \% \mathrm{~N}+$ consortium of endophytic bacteria foliar spray. The lowest uptake of $\mathrm{N}, \mathrm{P}$ and $\mathrm{K}(5.54,1.36$, and $3.76 \mathrm{~kg} \mathrm{ha}^{-1}$, respectively) was recorded in the treatment $\mathrm{T}_{1}$ (absolute control).

The total uptake of $\mathrm{N}, \mathrm{P}$ and $\mathrm{K}$ was highest $\left(243.91, \quad 60.20\right.$ and $205.47 \mathrm{~kg} \mathrm{ha}{ }^{-1}$, respectively) in the treatment $\mathrm{T}_{4}-25 \% \mathrm{~N}+$ consortium of endophytic bacteria foliar spray, and the lowest $(118.02,31.34$ and $82.99 \mathrm{~kg}$ ha 1 , respectively) was recorded in the treatment $\mathrm{T}_{1}$ (absolute control). 
Table.1 Effect of consortium of endophytic nitrogen fixing bacteria on nutrient uptake by seasonal sugarcane at harvest

\begin{tabular}{|c|c|c|c|c|c|c|c|c|c|}
\hline \multirow[t]{2}{*}{ Treatments } & \multicolumn{3}{|c|}{ Cane $\left(\mathrm{kg} \mathrm{ha}^{-1}\right)$} & \multicolumn{3}{|c|}{$\operatorname{Top}\left(\mathrm{kg} \mathrm{ha}^{-1}\right)$} & \multicolumn{3}{|c|}{ Total nutrient uptake $\left(\mathrm{kg} \mathrm{ha}^{-1}\right)$} \\
\hline & $\mathrm{N}$ & $\mathrm{P}$ & $\mathrm{K}$ & $\mathrm{N}$ & $\mathrm{P}$ & $\mathrm{K}$ & $\mathrm{N}$ & $\mathrm{P}$ & $\mathrm{K}$ \\
\hline $\mathrm{T}_{1}$ Absolute control & 112.49 & 29.98 & 79.22 & 5.54 & 1.36 & 3.76 & 118.02 & 31.34 & 82.99 \\
\hline $\mathrm{T}_{2}$ RDF $\left(100 \% \mathbf{N}, \mathrm{P}_{2} \mathrm{O}_{5}, \mathrm{~K}_{2} \mathrm{O}\right)$ & 211.63 & 53.78 & 168.32 & 8.12 & 1.71 & 7.13 & 219.75 & 55.49 & 175.45 \\
\hline $\mathrm{T}_{3} 50 \% \mathrm{~N}+$ Acetobacter diazotrophicus & 203.30 & 53.05 & 169.96 & 6.76 & 1.68 & 6.67 & 210.06 & 54.73 & 176.64 \\
\hline $\begin{array}{l}\mathrm{T}_{4} 25 \% \mathrm{~N}+\text { consortium of endophytic bacteria } \\
\text { foliar spray }\end{array}$ & 236.03 & 58.46 & 198.70 & 7.88 & 1.73 & 6.77 & 243.91 & 60.20 & 205.47 \\
\hline $\begin{array}{l}\mathrm{T}_{5} 0 \% \mathrm{~N}+\text { consortium of endophytic bacteria } \\
\text { Foliar spray }\end{array}$ & 178.11 & 48.08 & 169.10 & 7.30 & 1.90 & 7.45 & 185.40 & 49.98 & 176.55 \\
\hline $\begin{array}{l}\mathrm{T}_{6} 0 \% \mathrm{~N}+\text { without consortium of endophytic } \\
\text { bacteria foliar spray }\end{array}$ & 134.67 & 41.35 & 113.21 & 6.13 & 1.58 & 5.97 & 140.81 & 42.93 & 119.18 \\
\hline Mean & 179.37 & 47.45 & 149.75 & 6.95 & 1.66 & 6.29 & 186.33 & 49.11 & 156.05 \\
\hline S.Em. \pm & 8.45 & 2.33 & 14.04 & 0.22 & 0.06 & 0.59 & 8.46 & 2.34 & 14.05 \\
\hline CD at $5 \%$ & 25.47 & 7.01 & 42.33 & 0.68 & 0.18 & 1.77 & 25.51 & 7.04 & 42.36 \\
\hline
\end{tabular}

Table.2 Soil Nitrogen balance study under effect of consortium of endophytic nitrogen fixing bacteria on seasonal sugarcane

\begin{tabular}{|c|c|c|c|c|c|c|c|}
\hline $\begin{array}{l}\text { Sr. } \\
\text { No. }\end{array}$ & Treatments & $\begin{array}{l}\text { Initial } \\
\text { nitrogen }\end{array}$ & $\begin{array}{l}\text { Nitrogen } \\
\text { added }\end{array}$ & $\begin{array}{l}\text { Nitrogen } \\
\text { uptake }\end{array}$ & $\begin{array}{c}\text { Available } \\
\text { Nitrogen at } \\
\text { harvest }\end{array}$ & $\begin{array}{c}\text { Net gain } \\
\text { /loss of soil } \\
\text { nitrogen }\end{array}$ & $\begin{array}{c}\text { Nitrogen use } \\
\text { efficiency } \\
\mathrm{kg} \mathrm{kg}^{-1}\end{array}$ \\
\hline $\mathbf{T}_{1}$ & Absolute control & 134.8 & 0 & 118.02 & 119.17 & -102.39 & - \\
\hline $\mathbf{T}_{2}$ & $\operatorname{RDF}\left(100 \% \mathrm{~N}, \mathrm{P}_{2} \mathrm{O}_{5}, \mathrm{~K}_{2} \mathrm{O}\right)$ & 134.8 & 250 & 219.75 & 153.66 & 11.39 & 288.76 \\
\hline $\mathbf{T}_{3}$ & $50 \% \mathrm{~N}+$ Acetobacter diazotrophicus & 134.8 & 125 & 210.06 & 125.44 & -75.70 & 697.20 \\
\hline $\mathbf{T}_{4}$ & $\begin{array}{l}25 \% \mathrm{~N}+\text { consortium of endophytic } \\
\text { bacteria foliar spray }\end{array}$ & 134.8 & 62.5 & 243.91 & 169.34 & -215.95 & 1625.68 \\
\hline $\mathbf{T}_{5}$ & $\begin{array}{l}0 \% \mathrm{~N}+\text { consortium of endophytic } \\
\text { bacteria foliar spray }\end{array}$ & 134.8 & 0 & 185.40 & 137.98 & -188.58 & - \\
\hline $\mathrm{T}_{6}$ & $\begin{array}{l}0 \% \mathrm{~N}+\text { without consortium of } \\
\text { endophytic bacteria foliar spray }\end{array}$ & 134.8 & 0 & 140.81 & 116.03 & -122.03 & - \\
\hline
\end{tabular}


The increase in nutrient uptake with soil application of fertilizers and consortia foliar spray was due to increased availability of nutrients to plants. Drip irrigation improved the soil environment, which encouraged proliferous root system resulting in better absorption of moisture and nutrients. The results confirm the findings of Bhalerao et al., (2005), Muthukumarasamy et al., (2006), Saini et al., (2006) and Kumar (2012).

\section{Soil nitrogen balance study}

The data presented in Table 02 representing the Soil nitrogen balance study under effect of consortium of endophytic nitrogen fixing bacteria of seasonal sugarcane revealed that there was a negative balance of nitrogen due to application of $0 \% \mathrm{~N}\left(\mathrm{~T}_{1}\right), 50 \% \mathrm{~N}+$ Acetobacter diazotrophicus $\left(\mathrm{T}_{3}\right), 25 \% \mathrm{~N}+$ consortium spray $\left(\mathrm{T}_{4}\right), 0 \% \mathrm{~N}+$ consortium spray $\left(\mathrm{T}_{5}\right)$ and $0 \% \quad \mathrm{~N}$ without consortium spray $\left(\mathrm{T}_{6}\right)$.

The balance of $\mathrm{N}$ in $100 \%$ RDF treatment may be due to addition of organic manures and $100 \%$ inorganic nitrogen fertilizers which helped the plants for luxurious uptake as well as positive nitrogen balance in the soil. The nitrogen use efficiency of different treatments in split doses of nitrogen applied was $\mathrm{T}_{2}-\mathrm{RDF}\left(288.76 \mathrm{~kg} \mathrm{~kg}^{-1}\right), \mathrm{T}_{3}$ of $50 \% \mathrm{~N}+$ Acetobacter diazotrophicus $(697.20$ $\mathrm{kg} \mathrm{kg}$ ) and $\mathrm{T}_{4}-25 \% \mathrm{~N}+$ consortium of endophytic bacteria foliar spray $\left(1625.68 \mathrm{~kg} \mathrm{~kg}^{-1}\right)$ respectively.

Similar results were also reported by Kumar (2012). The gain in availability of $\mathrm{N}$ might be due to application of recommended dose of fertilizers, addition of $\mathrm{N}$ through FYM and native $\mathrm{N}$ in soil.

\section{References}

Ando, S. 2010. Nitrogen fixation associated with endophytic bacteria. In Nitrogen
Assimilation in Plants, Ed. Ohyama, T. and Sueyoshi, K. (Research Signpost, Kerala, India), pp. 215-231

Bhalerao, V. P., Jadhav, M. B. and Bhoi, P. G. 2005. Substitution of chemical fertilizers using different organics and studying their effects on soil properties, nutrient, uptake yield and quality of sugarcane. Co-op. Sug. 36(1): 903-908.

Dakora, F. O. and Phillips, D. A. 2002. Root exudates as mediators of mineral acquisition in low nutrient environments. Plant soil; 245: 23-31.

Dobbelaeve, S., Vanderleyden, J. and Okon, Y. 2003. Plant growth promoting effects of diazotrophs in the rhizosphere. Critical. Rev. Plant. Sci; 22: 107-149.

Kumar, N. 2012. Productivity, quality and nutrient balance in spring sugarcane (Saccharum spp. hybrid complex) under organic and inorganic nutrition, Indian J. Agron. 57(1): 68-73.

Muthukumarasamy, R., Govindarajan, M., Vadivelu, M. and Revathi, G. 2006. N fertilizer saving by the inoculation of Gluconacetobacter diazotrophicus and Herbaspirillum sp. in micropropagated sugarcane plants. Microbiol Res. 161: 238 245.

Panse, V. G. and Sukhatme, P. V. 1985. Statistical methods for agricultural workers. Fourth Ed. ICAR, New Delhi. 157-165.

Parkinson, J. A. and Allen, S. E. 1975. A wet oxidation procedure suitable for the determination of nitrogen and mineral nutrients in the biological material. Commun. Soil Sci. Pl. Anal. 6: 1-11.

Saini, S. K., Shashank Tyagi., and Dheer Singh. 2006. Nutrient (NPK) uptake as influenced by integrated nutrient management in spring planted sugarcane grown in sugarcane based cropping system. Indian Sug. 56(10): 67-72.

\section{How to cite this article:}

Rajkumar, B. and Bhakare, B.D. 2018. Effect of Consortium of Endophytic Nitrogen Fixing Bacteria on Nutrient Uptake and Soil Nitrogen Balance Study of Seasonal (SURU) Sugarcane under Drip Irrigation. Int.J.Curr.Microbiol.App.Sci. 7(03): 1512-1516.

doi: https://doi.org/10.20546/ijcmas.2018.703.180 